\title{
Correspondence
}

\section{The 'baby Brown' case and the Dr Arthur verdict}

SIR

There is cause for concern in the different outcomes of the trials in the cases of baby Brown's parents and Dr Leonard Arthur respectively. $\mathrm{Mr}$ Brown was found guilty of manslaughter and sentenced to five years imprisonment amid public opprobium for supposedly killing his 'mongol infant' (the euphemism is clumsy!), in drunken disappointment; whereas, Dr Arthur was acquitted amid almost universal plaudits having admittedly and dispassionately ordered doses of a medically unnecessary and potentially lethal sedative in order to make a no-feed regime tolerable to those responsible for the care of a similar baby also rejected by its parents. Does this mean that in future parents will reasonably expect their paediatricians to do away with unwanted handicapped babies on their behalf, when to do so themselves would put them in peril of the law and attract the disapproval of the mob-bearing in mind that the same baby, when at an advanced state of fetal development, could legitimately have been aborted? I well remember a distinguished obstetric colleague saying to me when I thoughtlessly expressed myself in favour of abortion on demand, on the grounds that babies need a facilitating environment after as well as before birth, retorting that he was in favour of infanticide on demand because in that case $I$, not he, would have to do it. The arguments about medical ethics in such situations do not sufficiently take into account the damage murder or infanticide, or abortion does to the 'executioner', however well intentioned he and his or her associates are. Does Professor Kennedy have an answer to this aspect of the problem?
JOHN A DAVIS

Professor of Paediatrics, University of Cambridge Clinical School, Department of Paediatrics, Cambridge CB2 $2 Q Q$

\section{Response to Professor Davis}

SIR

I am not sure I have an answer to Professor Davis's question. I can, however, offer a couple of observations. First, like him, I was interested in the different responses, publicly and legally, to the two cases. I had drawn attention to this possibility in my book in 1983 when I compared Dr Arthur's case with that of Nicholas Reed, the exsecretary of Exit, who was convicted of aiding and abetting suicide.

The legal analysis of Mr Brown's case, in the light of $R v$ Arthur is a bit complicated.

i. Take the following facts first; $\mathrm{Mr}$ Brown, instead of taking action to kill his child, opted to 'let nature take its course', at home, in the light of an unequivocal diagnosis by experts, by keeping the child sedated so that it did not request food and succumbed to an infection.

What fate would have been meted out to him? If he had been convicted of murder, then it would be hard to avoid a conclusion that there is one law for professionals and another for the rest. If he had not been charged or convicted of murder, then the law would, in the light of his real fate, seem to embrace (as it did in Dr Arthur's case) the distinction between killing and letting die (ignoring the fact that Dr Arthur prescribed drugs in the manner described by Professor Davis). But, this distinction is morally and legally untenable in circumstances in which the person involved has a legal duty to care for the child, as did both Dr Arthur and $\mathrm{Mr}$ Brown in their respective cases. So, in such a set of facts, both should be guilty, which is what I think the law requires, or neither should be guilty, which rests on an improper view of the law.

ii. Take, alternatively, the facts asci they were; $M r$ Brown took action to kill $\vec{G}$ his child. Mr Brown could have beenco convicted (as he was) on the basis that he intended to kill the child and took steps to achieve this end. This would belegally proper. It would also mean, $\mathcal{D}$ however, that Dr Arthur should haveo been convicted, unless the untenable $\vec{D}$ distinction between killing and letting die were improperly relied upon.

Alternatively, Mr Brown could hayebeen acquitted on the ground thast, there being no difference in between killing and letting die in the circumstances, his case is the same ass Dr Arthur's. This would mean that the law recognises that in exceptionah circumstances a child's life may be्क brought to an end at the parent's behest. This is what Dr Arthur's case may have $\overrightarrow{\bar{\sigma}}$ decided and accords with what many doctors and others think entirely? proper. The only debate, then, is abouto what circumstances are exceptional. $\mathrm{Mr}$ Brown's case seemed to fit within the criteria set out by $\mathrm{Mr}$ JusticéFarcquharson in $R v$ Arthur, in that the child was severely disabled (Down'si Syndrome) and rejected by the parent(s). This conclusion may concern some by suggesting that parents can lawfully 'do away with' their children. $D$ But, if they think the law is otherwise, they must accept that it will, on my analysis, apply just as much to the DP Arthurs of the world as to the MrN Browns.

This leads me to the second issue raised by Professor Davis. If doctors enjoy a special place (or immunity) in the law, they could, he fears, encounter pressure 'to do away with unwanted' handicapped babies'. In my view, ㄲ however, doctors enjoy no such speciaP place or immunity. Nor should they be asked to accept it nor be offered it.

Instead, the law should be clarified as 
a matter of urgency so that parents, doctors and the rest of us know where we stand and what we may do. Such clarification would perhaps indicate the circumstances, if any, under which a baby may be caused or allowed to die. This would then be the law which would be as applicable to parents as to doctors.

As I have said elsewhere, to call for such clarification finds all the usual moulders and makers of law running for cover. But some law or code must be drawn up if we are to avoid the situation Professor Davis adverts to.

IAN KENNEDY Professor of Medical Law and Ethics, Faculty of Laws, King's College, Strand, London WC2R 2LS

\section{Medical ethics - 'Trad and trend'}

SIR

Your principal editorial in the March issue (1) does well to draw attention to the two diverging concepts of medical ethics, roughly trad and trend.

Your contributors have evident dilemmas. 'Sometimes I have to remind myself to consult the patient' writes a clinician. A professor of sociology explains 'While codes of ethics appear to exist to protect the client, in practice they have a great deal more to do with the protection of the profession'.

From my viewpoint now in another discipline I find that the patients, whatever their intelligence, overwhelmingly revere and trust their own doctor and the medical profession; yet, I sense patients' vague but kindly doubts about medical ethics. According to the outlook of the speaker, I have heard such descriptions as: sanctuary of the Hippocratic altar; medical freemasonry; the doctors' rule-book. All said without acrimony, usually with puzzled amusement.

Perhaps with modern levelling, 'the obligations of a moral nature which govern the practice of medicine' are now as much on patient as on doctor, calling for better mutual understanding.

Sir, you may yet edit a fournal of Ethics in Medical Practice.

\section{References}

(1) Anonymous. Two concepts of medical ethics [editorial]. Fournal of medical ethics 1985; 11: 3 .

REVD DR WALTER HEDGCOCK MD FRCGP

3 Cherwell Close, Wallingford, Oxon $\mathrm{OX} 10 \mathrm{OHF}$

\section{Murder into manslaughter}

SIR

In his review of Susanne Dell's Murder into Manslaughter (1) Paul Sieghart expounds some serious misconceptions concerning what happens to people convicted of murder and manslaughter. I would like to put the record straight:

1. There has never been a time when all murderers were hanged, even before 1957,

2. A judge can only send a mentally abnormal person to a mental hospital provided he has two medical recommendations and the offer of a vacancy.

3. Sieghart is wrong in suggesting that officials in the Department of Health and Social Security determine whether offenders go to hospital or to prison. It has never been the case that a Special Hospital place was made 'whenever the courts wanted one'. What did happen in the 1970s is that vacancies were not offered in Special Hospitals for those who did not require special security even though the original charge had been murder. A typical example would have been of a depressed killer whose only victim was his wife, no other person was at risk and there was an expectation that the patient would respond to treatment in a matter of months.

4. The Butler Committee not only recommended no 'radical reforms' in this area but made no recommendations concerning the means of allocating beds in Special Hospitals. Neither did the Mental Health Act 1983 make any change to the statutory duty of the Secretary of State in this respect. Department of Health and Social Security officials act on behalf of the Secretary of State who is accountable to Parliament for his decisions or those taken on his behalf.

References

(1) Sieghart P. Fournal of medical ethics 1985; 11: 48

Medical Director, Broadmoor Hospital, Crowthorne, Berks RGII 7EG

\section{Response to Dr Hamilton}

SIR

1. Before 1957, hanging was the mandatory sentence which all judges had to pass on all murderers. Thereupon, they were hanged unless the Home Secretary exercised the Royal prerogative of mercy.

2. Quite so, and my review did not suggest otherwise. But what Ms Dell's research seems to show is that, if there are no prospects of a vacancy, there will be no medical recommendations.

3. So, if hospitals - including Special Hospitals - do not offer vacancies, people get sent to prison when they ought to be sent to hospital.

4. The Butler Committee drew attention to this state of affairs in its interim report, and made recommendations designed to resolve it. Among the reforms which the Committee proposed was a new law of insanity, and an end to the mandatory life sentence for murder - radical, surely, on any view. These reforms have still not been carried out - not even in the Mental Health Act 1983, which provided the last major opportunity. For all that, the Secretary of State is indeed accountable to Parliament. One can only hope that Ms Dell's book will increase the Parliamentary pressure on him to do something about it at long last.

PAUL SIEGHART

6 Gray's Inn Square, London WCIR 5AZ 